\title{
COMMUNITY SERVICES AND OUT-MIGRATION
}

\author{
Douglas S. Massey $^{\star \star}$, Nathalie Williams ${ }^{\star \star \star}$, William G. Axinn ${ }^{\star \star \star}$, and Dirgha J. Ghimire ${ }^{\star \star \star}$
}

Abstract

This paper investigates the relationship between changing community context and out-migration in one of today's poor countries, seeking to document the various mechanisms by which infrastructure affects the migratory behavior. We focus on the expansion of social and physical facilities and services near to rural people's homes, including transportation, new markets, employment, schools, health clinics, and mass media outlets such as movie halls. We draw upon detailed data from Nepal to estimate the hypothesized effects. The direct effects of expanding economic and human capital infrastructure are clearly negative, reducing out-migration. However, increased economic infrastructure is associated with a greater accumulation of human and social capital among respondents and their parents. Through these intervening mechanisms, economic and social infrastructure increased the odds of migrating out. These results reveal the often countervailing nature of short- and long-term effects of economic and social change and the complex pathways influencing migration outcomes.

\section{INTRODUCTION}

Researchers have long been interested in the relationship between migration and economic growth. Influences work in both directions, of course, with economic growth affecting migration and migration affecting growth. The latter relationship has been the subject of a vigorous debate between those who argue that migration retards economic growth and those who aver that it promotes economic expansion within migrant-sending communities (see Taylor et al. 1996a see Taylor et al. 1996b for reviews). Scholars in the former group emphasize the loss of labor power and human capital through out-migration (cf. Reichert 1981; Mines 1984), whereas the latter underscore the low opportunity costs of emigration from labor-abundant economies and the remittances that follow (Durand et al. 1996; Taylor 2004). Research suggests that in poor countries the positive effects of remittances on consumer demand and investment generally exceed the negative effects of lost labor and brain drain to yield a net positive contribution of migration to economic growth, although the size and direction of the effects vary depending on structural features of the national economy in question (Massey et al. 1998).

Considering the effect of economic change (or 'development') on migration, there is more of a consensus that economic change and associated social changes, promote out-migration (Hatton and Williamson 1994; Massey and Taylor 2004). In $19^{\text {th }}$ century Europe, for example, industrial expansion led to the consolidation of landholding, the substitution of machines for hand labor, and the commercialization of agriculture, which displaced rural dwellers from traditional livelihoods to create a mobile workforce in search of alternative support (Massey 1988). At the same time, the expansion of manufacturing and services in cities generated a demand for unskilled labor, leading to the urbanization of European

Direct all correspondence to: Nathalie Williams, Room 2267, Institute for Social Research, University of Michigan, PO Box 1248 , Ann Arbor, MI 48106-1248, USA; natw@umich.edu.

*** Princeton University

*** University of Michigan 
society through rural-urban migration (Thomas 1973). Given periodic market failures associated with the business cycle, however, urban labor markets frequently were unable to absorb arriving rural workers, and during periods of recession out-migrants from the countryside flowed overseas (Thomas 1941). Therefore, as Europe urbanized and industrialized between 1800 and 1929, it also exported 54 million workers to other parts of the world, mostly to the Americas (Hatton and Williamson 1998).

In this analysis, we focus on the relationship between economic growth and out-migration in one of today's poor countries, seeking to sort out the channels by which local transformations of economic and social infrastructure affect the migratory behavior of people. We focus on the expansion of social and physical facilities and services near to rural people's homes, including transportation infrastructure, new markets, employment, schools, health clinics, and mass media outlets such as movie halls. We draw on established theoretical concepts in the migration literature, including neo-classical economics (Harris and Todaro 1970), new economics of migration (Stark and Bloom 1985), world systems theory (Portes and Walton 1981, Petras 1981, Sassen 1988), and social networks (Massey et al 1987).

However, the strength of this paper is empirical - testing in one comprehensive model the long- and short-term effects of local infrastructure change on out-migration. Our empirical analyses are based in the Chitwan Valley of south-central Nepal. We take special advantage of this setting, which has undergone dramatic economic and social change and the reorganization of daily social life within the lifetimes of most of the current population (Axinn and Yabiku 2001).

\section{SOCIAL AND DEMOGRAPHIC CHANGE IN NEPAL}

Nepal is the one of the poorest countries in the world with a per capita income of only $\$ 311$ per person per year (United Nations Development Programme 2004; Asian Development Bank 2007). The economy has been-and continues to be-characterized by dependence on agriculture, with over $85 \%$ of the population still involved in the agriculture sector. Along with poor economic growth, high population growth and increasing environmental degradation, particularly in the most remote hilly parts of the country (Blaikie, Cameron, \& Sedon 1980; Macfarlane 1976) has lead to a massive movement of people from the Hills to the Southern plains (Conway and Shrestha 1981; Gurung et al 1983; Shrestha, Velu and Conway 1993).

However, beginning in the mid-1970s, Nepal experienced dramatic social and economic change when it started receiving large portions of its development budget in foreign aid. This flow of international aid was primarily targeted to improving the living conditions of the rural poor through improvement in education systems, health services, and rural infrastructure. The first signs of the effects of these changes quickly became apparent in the form of increasing participation in education, rising employment, exposure to mass media, international communication and travel, and other sociopolitical spheres of daily life (Axinn and Yabiku 2001; Beutel and Axinn 2002; Ghimire and Axinn 2006).

At the same time, the continuous flow of migrants from hilly areas along with persistent high fertility have turned the southern plains, which were once sparsely populated frontier areas, (KC 2003;Shrestha, Velu and Conway 1993), into the most densely populated settlements in the country. Consequently, high levels of in-migration, along with dramatic changes in daily economic and social activities, soon turned these once frontier areas into sources of potential migrants to other areas of Nepal and the outside world. During the latter part of the $20^{\text {th }}$ century, the plans, and specifically our study area in the Chitwan Valley, have come to be characterized by high levels of out-migration. This history of migration and 
economic and social changes makes this setting a unique laboratory in which to study the long- and short-term effects of economic and social change on migration behavior.

\section{CONCEPTUAL FRAMEWORK}

We argue that local social and economic service infrastructures have both direct and indirect effects on migration, both of which operate over the short and long run, and that their net effect is difficult to predict a priori. In the long run, economic and social services raise levels of health and education, generating human capital that for rural dwellers is likely to be more efficiently and profitably employed elsewhere, leading to out-migration (see Sjastaad 1962). In the short run, however, these infrastructures also increase local opportunities for employment and consumption that serve to anchor residents to the immediate area and thus inhibit migration (Todaro 1976).

We begin by outlining a conceptual model that captures these direct and indirect effects. The amount of economic and social infrastructure accessible during childhood is hypothesized to determine a person's capital endowments and achievements as an adult, whereas the level of infrastructure experienced in adulthood determines a person's current economic circumstances and opportunities. At this point in our theoretical discussion, we assume that this concept will apply to both men's and women's migration. However, past research has shown that migration is highly gendered, with men and women migrating at different rates and often for different reasons (Donato 1993, Pedraza 1991). Thus, it is likely that some of the mechanisms we discuss here will affect men to a greater extent than women, and others will affect women to a greater extent. With this in mind, we first describe our conceptual framework in general, without reference to gender, and then address the gender differences in detail in our analyses and the results section. 1

In our model, summarized in Figure 1, we distinguish between the infrastructure faced by respondents in the community they inhabited as children and as adults. The economic and social infrastructure relevant in determining a person's achievements and endowments lies in the past - the infrastructure and market resources available in a person's childhood community. At the time of the migratory decision itself, however, the relevant economic and social infrastructure is in the present community-those social and economic resources that are locally available when the mobility options are being contemplated.

As shown in Figure 1, infrastructure in the childhood community is hypothesized to determine an individual's capital endowments as well as achievements. For our purposes, achievements refer to the human and social capital that individuals generate for themselves during their lifetimes whereas endowments refer to capital generated by parents during their lifetimes2.

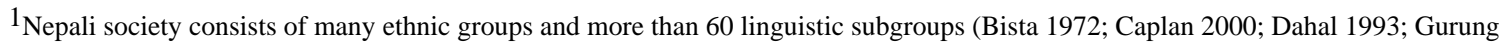
1980, 1998). Previous research in Nepal has shown strong links between ethnicity and both socioeconomic changes and migration (Graner, 2001; Graner and Gurung, 2003; Gurung et al, 1983). Thus it is likely that some of the mechanisms we discuss here will affect some ethnic groups to a greater extent than other. In general, because high caste Hindus, followed by Newars and Hill TibetoBurmese, enjoy the most socioeconomic and political power we would expect that the effect of economic growth on migration is likely to be much stronger for these ethnic groups than for low caste Hindus and Terai Tibeto-Burmese groups. To minimize the ethnic biases in our analyses, we have included ethnicity as control in all of our analytical models.

${ }^{2}$ We note that the temporal ordering of these factors could be different than shown in Figure 1. For example, an individual's capital endowments (from parents) could be fixed before an individual experiences their childhood community context. That is, parental education or other characteristics could lead parents to migrate and choose a different type of community before bearing children, which would then shape the individual's childhood community. To address this possibility we also estimate empirical models that treat endowments and childhood community context as correlated, rather than imposing a causal structure on the relationship of childhood context to endowments. We find the effects of childhood community context on migration quite similar in both models.
} 
Economic theories of migration postulate that human capital in the form of skills, knowledge, education, and experience allows greater benefits and less risk from outmigration, producing a higher likelihood of departure (Harris and Todaro 1970; Donato 1993; Massey and Espinosa 1997; Stark and Bloom 1985; Stark and Taylor 1991). Human capital endowments from one's parents are also likely to influence out-migration by offering people greater access to knowledge and financial resources. Social capital exists whenever a social tie to another person is of instrumental value in achieving some desired goal (Coleman 1988). When the goal is out-migration, the relevant connection is to someone with migratory experience (Massey 1990). Having a social tie to someone who has migrated in the past has been shown in numerous studies to lower the costs and risks of migration and, hence, to increase significantly the odds that any given individual will choose to move (Massey et al. 1998). If the tie is through one's parents the resulting social capital represents an endowment, if an individual forges his or her own ties to a migrant it is an attainment.

The model thus yields two indirect pathways to migration: the level of economic and social infrastructure in childhood affects an individual's capital endowments and achievements, which, in turn, affect the person's likelihood of out-migration in adulthood. As indicated by the signs associated with each pathway, these affects of childhood community infrastructure and endowments are generally positive: economic and social infrastructure increases one's access to various forms of capital and greater access to capital, in turn, promotes outmigration.

In contrast to the long-term effects, the short-term influences of economic and social infrastructure on migration are generally negative: the more developed the local infrastructure experienced in adulthood, the less likely people are to leave the community. As shown in Figure 1, the level of infrastructure in the adult community also yields direct and indirect pathways to migration. More infrastructure and services directly decrease the likelihood of out-migration by providing a broader array of local opportunities and resources -more jobs, higher wages, more consumption opportunities. Infrastructure and services also influence out-migration indirectly by changing current personal circumstances, or more specifically, by increasing the likelihood of local employment, making people less likely to migrate in search of jobs. The relative balance between these various positive and negative effects in the long- and short-term is the empirical question we seek to better understand in this paper.

\section{SETTING}

\section{Social and Physical Environment}

The setting for this study is the Western Chitwan Valley, in south central part of Nepal. Chitwan is a wide, flat valley nestled in the Himalayan foothills of south-central Nepal. Until the early 1950s, the region was covered by virgin forests and infested with malaria carrying mosquitoes. It was home to many different species of flora and fauna and the human population of the valley was limited to a few indigenous groups who lived along river banks and survived through hunting and fishing with virtually no physical infrastructure.

Beginning in the mid-1950s the Nepalese government opened this valley for settlement by clearing the forest, eradicating malaria, distributing land to people from the highlands, and building new roads, irrigation projects, and government services. These services included investments aimed at improving agricultural production, such as cooperatives and Nepal's largest agriculture research and training program (Shrestha 1989; Yadav 1997). 
The Chitwan Valley remained a remote and isolated frontier region until 1979, however, when the first all-weather roads were completed to link Chitwan to Kathmandu and other cities throughout Nepal and India (Shrestha et al. 1993). Because of Chitwan's central location, by the mid-1980s, this once isolated valley had become a major transportation hub for the entire country. This change was accompanied by a proliferation of government services, agriculture improvements, business enterprises, and employment (Pokharel and Shivakoti 1986; Axinn and Yabiku 2001).

Figure 2 presents the trajectory of economic and social infrastructure change within the Chitwan Valley by showing changes in travel time required to access various economic institutions and services. As can be seen, within the lifetimes of most residents, Chitwan's pattern of social and economic organization was radically transformed. By the late 1990s, the proliferation of neighborhood service organizations had shifted land use away from forestry and agriculture toward buildings and physical infrastructure (Axinn and Ghimire 2002; Shivakoti et al 1999). Schools were the first type of local infrastructure to be built. In 1955 the average resident of Chitwan faced more than an hour's walk to the nearest school. However, by 1965 the walk had dropped to around 23 minutes and this trend continued downward to reach around 12 minutes by the mid 1990s. Next to emerge were markets, bus services, and employment establishments. Travel time to these resources began to drop in the mid 1960s and by the 1990s had reached about 10-20 minutes. The last type of infrastructure to arrive was health services. As late as 1970 Chitwan residents could expect to walk an hour to visit a clinic or hospital, but by 1995 the travel time had been reduced to around 22 minutes.

\section{Migration Patterns in the Chitwan Valley}

As in the rest of Nepal, internal and international movements are common livelihood strategies for Chitwan Valley residents. Much migration is seasonal and is viewed as a strategy to supplement regular farm and household incomes (Thieme and Wyss 2005; Kollmair et al 2006). For domestic migrants, agricultural work is common (HMG et al 2004), as well as urban wage labor in carpet factories, as domestic workers, and other informal jobs (Graner 2001). It is difficult to measure the volume of internal migration. Among all households in Western terai rural areas (where Chitwan is situated) that received migrant remittances in 2003-04, however, $42 \%$ received remittances from migrants within Nepal (HMG et al 2004).

International migration is also common, especially in the Chitwan district, as it shares an open border with India. Although official sources registered about 760,000 Nepalese living abroad in 2001 (HMG et al 2002), estimates of registered and unregistered migrants abroad range from 1.3 to 3 million people, comprising 6.5 to $14.7 \%$ of Nepal's population.

(Kollmair et al 2006). A little more than three quarters (77\%) of these international migrants are estimated to be in India; but large numbers of Nepalese travel to other countries in South Asia and the Middle East (HMG et al 2002; Seddon et al 2002). In the Chitwan district, 2.5$5 \%$ of residents are believed to be living abroad at any one time (HMG et al 2002; Thieme et al 2005). International migrants have historically worked in agriculture, construction, mining, and as soldiers in the British and Indian armies (Thieme and Wyss 2005).

\section{Gender in Nepal}

Nepalese society has historically been strictly stratified by sex. Men and women experience very different opportunities and expectations regarding work, relationships, personal autonomy, and decision-making power (Fricke, Axinn, and Thornton 1993; Niraula and Morgan 1996; Yabiku 2005). This gendered opportunity structure may ultimately limit individual women's ability to decide to migrate and to build a life in a destination 
community, as well as constraining their decision-making power with regard to family moves. In a gendered social context, migration is affected by different mechanisms for men and women. Upon marriage, young couples most often reside with the groom's parents for many years (Reed and Reed 1968; Bennett 1983; Shrestha and Bhattarai 2003; Yabiku 2005). Functionally, marriage instigates migration among women to a much greater extent than among men.

Men on the other hand, are much more likely than women to move for reasons other than marriage, such as employment, education, or military service. In 1980, men in Nepal had much higher rates of employment outside the home and around $66 \%$ of the labour force was male (World Bank Group 2004). In 1991, there were twice as many boys as girls enrolled in secondary school and the military service was almost solely comprised of men (Acharya, Mathema, and Acharya 1999).

However, norms for women and men differ and are changing in many Nepali communities. Research has shown that female autonomy, decision-making abilities, and ultimately the ability of women to migrate are changing as ideas and institutions evolve throughout Nepal (Niraula and Morgon 1996). Women increasingly participate in the paid labor force and the gender gap in education is consistently decreasing with time (Williams 2006). The declining educational gap may affect gender differences in migration in the coming years. We suspect that, as with men, women's migration decisions will increasingly be determined by education and employment opportunities.

\section{DATA AND METHODS}

In order to operationalize the conceptual framework, we draw upon data from the Chitwan Valley Family Study (CVFS), a large multidisciplinary longitudinal study designed to investigate the impact of macro-level socioeconomic changes on micro-level individual behavior. Here we draw on measures of individual experience and neighborhood characteristics collected in 1996. For survey purposes, the Chitwan Valley was divided into a set of mutually exclusive "neighborhoods," geographic clusters of 5-15 households that were selected on an equal probability basis using multi-stage sampling (Barber et al. 1997). Once selected, a history of each neighborhood was compiled using a neighborhood history calendar (Axinn et al. 1999). These calendars record the time to walk to neighborhood services and facilities in minutes for each year from 1953 to 1995.

Calendar methods have been shown to provide accurate retrospective measures of the history of economic development (access to economic activities and enterprises) within the respondent's place of residence (Axinn et al. 1997). Moreover, the Neighborhood History Calendar used in the CVFS was specially designed to use national and local events to help respondents recall the timing of neighborhood level changes (Axinn et al 1999). These measures of neighborhood level changes have been extensively used in previous research and found to be highly reliable (Axinn and Yabiku 2001; Axinn and Barber 2001; Barber 2004; Beutel and Axinn 2002; Brauner-Otto et al. 2007; Hoelter et al. 2004; Pienta et al. 2001; Shivakoti et al. 1999; Yabiku 2004, 2005, 2006).

Once a neighborhood history was collected, researchers surveyed every household within it, yielding a total of 1,583 households across the 151 neighborhoods, with a $100 \%$ response rate at the household level. After the household survey was completed, all individuals of economically active and demographically dense age (15-59) residing in the household were interviewed using a standardized questionnaire and a life history calendar, along with spouses of respondents who lived elsewhere or who were outside this age range. A total of 5,271 individuals, ages 13 to 80 with a mean age of 32 years, were interviewed, with a 97\% 
response rate. Some $51 \%$ of the sample was female, $46 \%$ were high caste Hindus, $17 \%$ hill Tibeto-Burmese, $17 \%$ Terai Tibeto-Burmese, $11 \%$ low caste Hindus, $6 \%$ Newars, and $3 \%$ were other ethnicities.

Together, the interviews yielded detailed information on family background, personal characteristics, daily experiences, and childhood community context3. Common identifiers allow events from the life history survey to be linked to personal and contextual characteristics in the baseline household questionnaire. The Life History Calendar yields retrospective data on place of residence, marital status, children, living arrangements, schooling, and work experience, as well as migration (Axinn et al. 1999). It has been shown to yield accurate retrospective measurement of life events and the characteristics of those events (Belli 1998;Freedman et. al.1988) and the instrument used in the CVFS was specially designed to use local events to help respondents recall the timing of personal events and to allow respondents to report their recall of marital events in a manner most consistent with local practices (Axinn et al 1999). We rely on the special strengths of this method to measure the sequences of events in individuals' lives and to develop models of the impact of economic changes on the likelihood individuals out migration.

Table 1 lists the measures, definitions, and descriptive statistics for different variables included under the conceptual categories depicted in Figure 1. We measure community infrastructure in childhood using two indices. An economic index assesses which of four basic resources was available within a 60-minute walk of the respondent's childhood home. These economic resources included a market (any place with two or more retail shops); bus service (a regular bus stop); any government program (for agriculture, forestation, road construction, electrification, or some other development activity), and any employer (any organization employing more than ten people). Many employers who employ fewer than ten people are seasonal in nature, thus we include only those employers who employed more then ten people to capture the more permanent employment centers. Each variable was coded 1 if the resource was accessible within 60 minutes and 0 otherwise. The final index of community infrastructure summed the individual items and divided by four to yield a measure that ranges from 0 to 1.0 in increments of 0.25 .

The second index focused on access to human capital infrastructure. It determined which of five basic kinds of human capital-related resources were available within a 60 minute walk of the childhood home: a clinic or health center, a school, a women's group, a temple, and a police station. A women's group consisted of any group organized on behalf of women by health volunteers (for singing, dancing, self improvement, local development, or other activities). As before, we coded each indicator as 1 if the human capital resource was accessible within 60 minutes walk and 0 otherwise. The final index was the sum of these indicators divided by five, yielding a measure that range from 0 to 1.0 in increments of 0.20 .

We defined the adult economic and human capital indices using similar indicators, except that we changed the travel time involved. Given the rapid change in the Chitwan Valley and the high degree of infrastructure development, by 1996 virtually everyone had come to live within an hour's walk of the resources under consideration. Thus, access to resources in the adult community was measured in terms of a five-minute rather than a 60 -minute walk. A five-minute walk identifies organizations and services with which the individual interacts on a daily basis (Axinn and Yabiku 2001). The adult economic index included five basic measures and the human capital index included three. The economic index, which ranges from 0 to 1.0, is the share (in 0.20 increments) of the following five resources that are accessible within a five minute walk in the adult community: bank, bus stop, employer,

\footnotetext{
${ }^{3}$ For our analyses, we use the term 'childhood community' to refer to the community inhabited until the respondent was 12 years old.
} 
market, and government program. The human capital index, which again ranges from 0 to 1.0 , is the share (in 0.33 increments) of the following three organizations accessible within a five minute walk: a health center, a school, and a temple.

We measured human capital endowments in terms of mother's and father's education and labor market experience (see Becker 1994). We assumed that respondents from families in which the mother or father worked and was educated offered greater access to human capital than those in which the parents did not display these outcomes. We thus defined dummy variables to indicate whether or not the respondent's mother attended school before the respondent was age 12, whether or not the respondent's father attended school before the respondent was age 12, whether or not the mother worked outside the home before the respondent was age 12, and whether or not the father worked outside the home before the respondent was age 12 . We assess social capital endowments by determining whether the respondent's mother and father had traveled outside of the Chitwan Valley before the respondent was aged 12, coding each indicator as 1 if the parent traveled and 0 otherwise.

Human capital achievements refer to the education and experience of respondents themselves, not their parents. We measured human capital as years of schooling completed and labor market experience, with the latter being differentiated by whether work was for salary or wages. Migration-specific human capital was measured as the number of trips the respondent had taken outside of Chitwan and current economic circumstances in terms of whether or not the respondent was currently employed for pay.

The foregoing variables constitute theoretical indices corresponding to the conceptual categories shown in Figure 1. In measuring their effects, we seek to control for a variety of demographic circumstances, including number of children in the household, marital status, living arrangements, history of mobility into the Chitwan Valley, ethnic group, age, and duration (time since the respondent last attended school). The control variables are also listed and defined in Table 1.

In order to estimate the direct and indirect, as well as long- and short-term effects of community context on migration, we start by estimating a series of cross-sectional regressions of how a person's childhood community influences their human and social capital endowments and achievements. We then estimate an event history model to examine how the fixed effects of adult and childhood infrastructure, along with endowments and achievements, influence the annual probability of out-migration to locations outside the Chitwan Valley.

\section{RESULTS}

\section{Infrastructure and Capital Endowments}

In order to assess the effect of childhood community infrastructure on intermediate variables we estimated a series of cross-sectional regressions to predict both endowments and achievements of human and social capital at the time of the baseline survey, given the economic and social infrastructure available to the respondent in childhood, controlling for other background characteristics. Table 2, for example, estimates of the effect of childhood community infrastructure on mother's education and labor market experience, two indicators of human capital endowments. As expected, mother's education is strongly and significantly associated with the economic infrastructure that was accessible to the respondent during childhood. This is likely because economic infrastructure provides an opportunity to use the skills, knowledge, and credentials gained from education, and thus gives individuals in these communities more incentive to go to school. The greater the access to markets, employers, 
buses, and government programs, the greater the education of the respondent's mother and the more likely she was to have worked before the respondent turned 12 .

Once the influence of economic infrastructure is held constant, access to human capital resources in childhood did not significantly affect mother's education. However, the effect on mother's labor market experience was significantly negative. Thus, access to infrastructure supporting the cultivation of human capital appears to discourage mothers' entry into the paid workforce, most likely because access to schools (one of the variables included in the human capital index) increases the odds that a mother is enrolled in continued full-time education, which precludes participation in the paid workforce.

Table 3 estimates similar models of the effect of childhood community infrastructure on father's education and labor market experience. The effect of economic infrastructure during the respondent's childhood community was again significantly and positively associated with father's education and labor market experience. Access to human capital resources in childhood also had a positive and significant effect on father's education but once more had a negative influence on father's labor market experience. As before, this pattern occurs because access to schools and continued education is likely to compete for a father's time and thus increase the age at which he will be able to enter the labor force.

Table 4 shows the effect of childhood community infrastructure on social capital endowments by estimating how access to economic and human capital infrastructure affects the likelihood of having a parent with migratory experience. In both cases, greater resources in the childhood community dramatically increased the odds of having a mother and father who left the valley before the respondent was aged 12 . Whereas the effect of access to economic infrastructure on out-migration was not significantly different for mothers and fathers, the effect of access to human capital infrastructure was significantly stronger in predicting the migratory experience of mothers than fathers. The respective logistic regression coefficients are 1.266 for the former and 0.461 for the latter, a significant difference at $\mathrm{p}<0.01$. In general, Chitwan has more human capital services (more schools, health centers, women's groups, temples, and police) than other areas in Nepal (Shrestha 1989 ; Yadav 1997). Thus greater access to services in the resident community may have discouraged migration of those parents who might otherwise have migrated or traveled to gain access to these services.

\section{Infrastructure and Capital Achievements}

Next we examine the effect of access to economic and human capital infrastructure on respondents' human capital achievements. Table 5 shows the results of cross-sectional Ordinary Least Squares (OLS) regression models (Fox 1997) that predict respondents' years of schooling, number of trips made outside of Chitwan, wage work experience, and salaried work experience. As can be seen, growing up in a community with more resources has very strong, positive, and significant effects on education. As childhood access to economic infrastructure moves from its minimum of zero to its maximum of 1.0, schooling increases by 2.5 years. Likewise, as the index of human capital infrastructure goes from its minimum to maximum, education increases by 1.3 years.

Taken together, these two effects imply that growing up in with the greatest access to infrastructure would yield 3.8 more years of schooling compared with growing up with the least access. These results are not surprising, of course. The availability of non-family institutions and employment opportunities yield a community context in which individuals have more to gain from the specific skill set that is taught in formal education programs. Thus children are more likely to attend school. This result of course is likely driven more by 
male participation in schooling and non-family employment than by female participation. We address this issue in later analyses that are separated by gender (in Table 8).

The amount of community infrastructure available also appears to have a positive effect on migration-specific human capital; but only the index of human capital infrastructure is statistically significant. The greater the access to human capital infrastructure in childhood, the more trips respondents themselves were likely to have taken by the time of the survey. As other studies have found, out-migration is not always associated with a lack of infrastructure or services, but is often linked to development of infrastructure itself (Morawska 1990, Petras 1981, Portes and Walton 1981, Sassen 1988). An important driver in this relationship may be human capital formation (Massey et al. 1998). Growing up with access to schools, health clinics, and other organizations that cultivate the formation of human capital raises the odds that a person will have prior migrant experience, and those that have migrated in the past are much more likely to migrate again in the future than those who lack migrant experience.

The level of a community's economic infrastructure is not related to the accumulation of salaried work experience, nor is it related to wage work experience. However, the amount of human capital resources experienced in the childhood community is strongly and significantly related to both kinds of work experience, although in opposite directions. Whereas human capital infrastructure is negatively related to years of wage work accumulated, it is positively related to years salary work. We interpret this finding to indicate the greater possibilities for occupational mobility when human capital is accessible. As access to human capital infrastructure during childhood increases, wage labor experience is markedly reduced and is replaced by greater experience in salaried job categories that are contingent on prior education. In other words, coming of age in a community with schools, clinics, and other human capital-related institutions apparently delays entry into the low end of the labor force by making education a viable option to entry-level work, and then facilitates entry into higher status positions.

The final intervening variable we consider in the path from community infrastructure to migration is current employment. Results from a cross-sectional OLS regression model predicting current employment are presented in Table 6. In this model, however, we relate indicators of economic and human capital infrastructure present in the adult community to the likelihood of current employment. These results reconfirm the foregoing conclusion regarding the nature of the influence of human capital infrastructure on wage work. The presence of such infrastructure not only suppresses the accumulation of wage labor experience, it also diminishes the odds of paid employment during the present. The coefficient of -0.824 is very strong and highly statistically significant. Thus, the more institutions capable of cultivating human capital accessible locally, the less likely people are to enter the labor force. At any point in time (in this case the date of the 1996 survey), greater access to human capital infrastructure increases the chances individuals are pursuing alternatives to work, such as education and training.

Holding constant the effect of human capital infrastructure, however, the presence of economic infrastructure is strongly and positively related to the odds of employment. The coefficient of 0.676 , indicates that economic infrastructure in the current communityemployment opportunities, buses, markets, and banks—provide direct opportunities for employment and thereby increase the likelihood of current employment for those who live in these communities. These opposite effects of economic and social infrastructure on current employment once again illustrate the complexity of the influence of local infrastructure on socioeconomic outcomes. 


\section{Infrastructure and Migration}

The foregoing cross-sectional analyses have explored the influence of community economic and human capital infrastructure on various intervening variables hypothesized to mediate the effect of community infrastructure on the odds of out-migration. Here we turn to an event history analysis to study the effect of these intermediate variables on the relative likelihood of departure, or more specifically of taking a trip lasting 6 months or more outside the Chitwan Valley. Using data compiled from the life history calendar, we follow respondents year-by-year from the time they finish schooling or reach the age of 12, whichever comes later, to the date of the baseline survey. We measure the amount of community infrastructure in childhood and adulthood as fixed, along with fixed endowments of human and social capital. Education likewise constitutes a fixed effect by virtue of the fact that the event history begins when schooling ends. We then construct time-varying indicators of wage and salary work experience, previous travel experience, and current employment, along with simultaneous time-varying controls for family size, marital status, living arrangements, age and duration of time since the respondent last attended school. Among control variables, gender, mobility history into the valley, and ethnicity are also fixed in time.

Together the set of time-fixed and time-varying indicators at time $t$ are used to predict the likelihood of migrating out in year $t+1$. The outcome is coded as 1 if the respondent migrated during the person year in question and 0 otherwise. All person-years subsequent to the first post-schooling trip are excluded. This outcome was regressed on the predictor variables using logistic regression and the results are shown in Table 7.

As hypothesized in our model shown in Figure 1, the economic and social infrastructure that respondents experienced in childhood has no direct effect on current migratory behavior. The effects of community infrastructure in childhood are thus all indirect, occurring through their prior influence on capital achievements and endowments.

As predicted, the level of economic and social infrastructure in adulthood is negatively related to the odds of out-migration from Chitwan. Not surprisingly, the more economic opportunities and human capital resources that are available locally, the less likely people are to leave in search of income, employment, or services elsewhere. Human capital achievements and human capital endowments are positively related to the likelihood of leaving the valley. Respondents whose mother gained schooling and work experience during their childhood were significantly more likely to migrate. However, father's schooling and work experience had no significant effect on the respondents' likelihood of migration. This is likely because father's education and work experience are more the norm than mother's. These experiences do not set fathers and their families apart from others as much as mother's experiences with education and schooling do. With respect to human capital achievements in this model, each additional year of schooling earned by respondents increased their odds of out-migration by around 5\%. Once education was controlled, years of salary or wage work had no significant effect on migration.

In contrast to expectations, however, prior migratory experience was negatively related to the likelihood of an additional departure. The more trips a person has made in the past, the less likely he or she is to seek to leave the valley again. The latter result suggests that a pattern of circular migration may prevail in the Chitwan Valley, whereby households use migration instrumentally as a means of solving an economic problem at home. They migrate to finance a particular project - such as the purchase of land, construction of a home, the acquisition of education-and once that need has been met through remittances or savings, the migrant returns and is relatively unlikely to leave again. Such a pattern is consistent with the migratory motivations postulated by the New Economics of Labor Migration (see Stark 
1991; Massey et al. 1998) and has been documented in studies of migration and remittances in other areas of Nepal (Kollmair et al 2006; Seddon et al 2002; Thieme and Wyss 2005).

Our results indicate that out-migration is strongly predicted by social capital, although the effects of social networks are highly gendered. Whereas having a father with migrant experience greatly increases the odds that respondents will themselves leave the valley, having a mother with such experience has no effect on the likelihood of out-migration. As in Mexico (see Cerrutti and Massey 2001), migration in Nepal thus appears to be a male-led phenomenon achieved through male social networks. These results are similar to those of other studies in Nepal that have found both greater numbers of men migrating and male-led migration social networks (Seddon et al 2002; Thieme and Wyss 2005).

In order to test for gender interactions in the determination of migration, Table 8 reestimates the discrete time event history model separately for men and women. As before, childhood community infrastructure has no direct effect on the migratory behavior of respondents of either sex. However, the economic and human capital infrastructure in the adult community appears to have very different effects on the odds of male and female migration. Among men, the effect of greater access to economic and human capital infrastructure is unambiguously significant and negative: the greater the access to infrastructure in the adult community, the lower the odds of departing from the Chitwan Valley on a trip of at least six months.

Among women, in contrast, access to additional human capital infrastructure has no significant effect on the odds of out-migration from Chitwan. However, the effect of access to economic infrastructure is significant and positive. Greater community infrastructure thus appears to promote female migration but inhibit the movement of males. This important gender difference may be a product of gender differences in the links among economic services and opportunities, marital behavior, and migration. Previous research from this setting shows that women tend to leave school for marriage and family related reasons whereas men tend to leave school for work and economic opportunity (Beutel and Axinn 2002). Marriage behavior is likely to produce gender differences in migration in Nepal because for many Nepalese ethnic groups, at marriage women tend to move some significant distance to move into their new husband's home (Bennett 1983). It may be that local economic opportunities attract men to stay, but increase women's rates of marriage, leading to out-migration.

As in the overall model, in the gender-specific models the effects of human and social capital endowments and human capital achievements are generally positive, with the exception of prior migratory experience. Having an educated mother with labor market experience significantly increases the odds of out-migration by women as well as men. Although the coefficient relating mother's education to out-migration is not significant for women (0.462), neither is it very different from the significant coefficient observed for males (0.401). Similar to the overall model, father's education and labor market experience have no effect on either men's or women's migration. Social capital appears to work to promote out-migration only through the father and not the mother. Having a father with prior migrant experience greatly increases the odds of out-migration for both men and women whereas having a migrant mother has no effect on the migratory behavior of either gender. These differences in the consequences of fathers' and mothers' migration experiences may be related to differences in the nature of men's and women's migration experience in Nepal. More research is needed on the gender differences in these experiences and on how extended social networks (including other relatives, neighbors, and friends) affect men's and women's migration. 
Among the human capital achievements we take into account, education has a powerful effect in promoting the migration of men but not women. Each additional year of schooling raises the odds of out-migration by around $6 \%$ for men, whereas the effect on women is zero. Moreover, whereas prior migratory experience reduces the odds of male migration, it has no effect on the movement of females. Thus, each additional trip taken by males lowers their odds of migration by around $13 \%$, but has no statistically detectable effect on the odds of female migration. Among both men and women, however, current employment significantly lowers the odds of out-migration and to roughly the same extent, reducing the odds of movement by around $36 \%-38 \%$.

Some of the control variables also display interesting gender interactions. As one might expect, the presence of children reduces the odds of migration, but the effect is much stronger for females (often the primary care givers) than males. Likewise, marital status only modestly affects the likelihood of migration by males but has strong effects on the odds of migration by females. Because most ethnic groups in this part of Nepal are patrilocal, there is considerable marriage migration among women but not men (Bennett 1983). Whereas getting married in the current person year is associated with a huge increase in the odds of female migration, it has no influence at all on the likelihood that males move. Widowhood is also associated with a high likelihood of movement by women, but not men, and being married but not living with one's spouse does have a positive effect on the migration of both genders, but the influence is much larger for females. Finally, whereas having an inresidence spouse lowers the odds of migration for males, it raises the odds for females.

With respect to living arrangements, living with relatives is associated with a higher probability of migration by women but not men, but other non-family living arrangements are associated with higher odds of migration by both groups. With respect to age, the likelihood of migration declines sharply and significantly as age rises above 40 for men; but the migration-age curve for females is flat, with no significant effect of age at all. Moreover, whereas both groups display a declining likelihood of migration with duration, the drop over time is steeper for females than males, suggesting a greater underlying inertia for women.

\section{Direct and Indirect Effects of Community Infrastructure}

The foregoing analyses provide us with the raw information we need to sort out the direct and indirect effects of community economic and social infrastructure on migration over the short and long term. In the long run, the level of economic and social infrastructure available in childhood is generally associated with larger endowments of human and social capital and greater human capital achievements. These, in turn, translate into higher probabilities of outmigration in adulthood. In the short run, however, community context increases the odds of current employment, which reduces the likelihood of out-migration indirectly, and provides a wider array of opportunities and resources for local consumption, which reduces it directly.

To conclude our analysis, and to sort out the balance of positive and negative effects, we draw upon OLS estimates of the foregoing equations to conduct a path analysis of how community infrastructure directly and indirectly affects out-migration. That is, for the dichotomous outcomes we assume a linear probability model and then used standardized regression coefficients from the resulting estimated equation to compute effect sizes. The results of this exercise are presented in Table 9, which computes the indirect effect of childhood community economic infrastructure on migration through human and social capital endowments and human capital achievements, and the indirect effect of childhood human capital infrastructure on migration through the same intermediary factors. We also estimate the indirect effect of adult economic and social infrastructure on migration through 
employment, as well as their direct effects on the odds of leaving Chitwan. The various direct and indirect effects are summarized at the bottom of the table.

According to our estimates, the direct and indirect effects of community infrastructure work in opposite directions. The direct effect $(-0.180)$ is naturally negative. More banks, buses, employers, markets, and government programs in the community increase local employment and earnings opportunities to reduce the odds of migration. At the same time, over the long run, growing up in a setting with more economic and social resources has a net positive effect on migration (0.202). In such a setting, one's parents have more opportunities to earn money and finance human capital formation, and individuals have access to more resources to invest in their own human capital. Subtracting the direct and indirect effects yields a modest positive residual (0.020), which helps to explain why the estimated effect of increases in community infrastructure on migration is often positive (Massey and Espinosa 1997; Lindstrom and Lauster 2000).

In contrast, the overall effect of human capital infrastructure is unambiguously negative. Directly, greater human capital infrastructure is associated with expanded opportunities nearby to reduce the odds of out-migration $(-0.100)$, and while there are a host of indirect effects they tend to be individually modest and of different signs, so as to cancel one another out, yielding a total indirect effect of just 0.009. Although human capital infrastructure raises the odds of out-migration by increasing the respondent's education as well as his or her mother's and father's, and by increasing father's migration experience, it decreases it by lowering mother's employment levels and the respondent's wage labor experience while increasing the respondent's migratory experience.

\section{CONCLUSION}

In this analysis we have examined how changes in local community infrastructure affect patterns and processes of internal out-migration using data from Nepal's Chitwan Valley. We estimated a series of cross-sectional regressions to assess how growing up in a community with access to more economic and social resources influenced a person's endowments and achievements with respect to human and social capital. We then estimated an event history model to examine how the effects of one's adult and childhood infrastructure, and the endowments and achievements of capital they determine, influence the annual probability of out-migration to locations outside the Chitwan Valley, while controlling for time-varying individual characteristics.

This analysis is based on a model that conceptualizes community economic and social infrastructure as influencing out-migration through a combination of direct and indirect pathways that play out over the long and short run. Directly, resources within one's immediate community create opportunities for employment and earning that root one to the locality and reduce the odds of out-migration. Indirectly, however, community resources increase endowments and achievements with respect to human and social capital that raise the returns of a potential move and thus increase the odds of migration.

Our empirical estimates document the complex interplay between direct and indirect, shortand long-term effects to illustrate how the observed relationship between migration and new community infrastructure associated with economic growth may be indeterminate a priori. In Nepal's Chitwan Valley, the direct effects of expanding economic and human capital infrastructure were clearly negative, as expected. However, the increased economic infrastructure was found to be associated with a greater accumulation of human and social capital among respondents' parents and greater human and social capital achievements by respondents themselves. Through these intervening variables economic and social 
infrastructure increased, rather than decreased, the odds of making a move within Nepal during the period under observation.

Based on this analysis we do not assert that the particular pattern of direct and indirect effects documented here will necessarily be replicated in other settings. The point is not that the complex interrelationship of institutional expansion, capital endowments, capital achievements, and mobility play out similarly in all times and places, but to alert researchers to the often countervailing nature of short- and long-term effects of economic and social change and the complex pathways by which migration outcomes may be determined. Of course, migration itself may feed back on community change through the effects of lost labor, brain drain, and remittance flows. We have not attempted to model those effects here, but intend to address them in future research.

In addition to the theoretical implications, this analysis also contributes to policy and programs, especially in the areas of rural development and migration policy. With respect to rural development programs, which aim to revitalize rural communities, it is important to understand how new social and economic resources may increase or decrease rural outmigration. The differing results of community-level resources in the short- and long-run should alert program designers of the need to carefully consider the long-term influences of new services in rural areas.

\section{Acknowledgments}

This research was supported by a grant from the National Institute of Child Health and Human Development (grant \#R01-HD33551) and a center grant from the Fogarty International Center to Population Studies Center at the University of Michigan. We thank Sarah Brauner, Heather Gatny, Paul Schulz, and Cathy Sun for their assistance creating analysis files, constructing measures, conducting the analyses, and documenting key aspects of our findings. We also would like to thank staff of the Population and Ecology Research Laboratory in Nepal for their contributions to the research reported here.

\section{References}

Acharya, M.; Mathema, P.; Acharya, B. Women in Nepal: Country Gender Assessment. Manila, Philippines: Asian Development Bank; 1999.

Asian Development Bank. Key Indicators 2007: Economic and Social Statistics Database. 2007 [March 12, 2008]. Accessed at http://www.adb.org/Documents/Books/Key_Indicators/2007/pdf/NEP.pdf

Axinn, William G.; Barber, Jennifer S. Mass Education and Fertility Transition. American Sociological Review. 2001; 66:481-505.

Axinn, William G.; Ghimire, Dirgha J.; Barber, Jennifer S. The Neighborhood History Calendar: A Data Collection Method Designed for Dynamic Multilevel Modeling. Sociological Methodology. 1997; 27(1):355-392. [PubMed: 12348199]

Axinn, William G.; Ghimire, Dirgha J. Population and Environment: The Impact of Fertility on Land Use in an Agricultural Society. Paper presented at the Annual Meeting of the Population Association of America; May 9-11; Atlanta, GA. 2002.

Axinn, William G.; Pearce, Lisa D.; Ghimire, Dirgha J. Innovations in Life History Calendar Applications. Social Science Research. 1999; 28:243-264.

Axinn, William G.; Yabiku, Scott T. Social Change, the Social Organization of Families, and Fertility Limitation. American Journal of Sociology. 2001; 106:1219-1261.

Barber, Jennifer S. Community Social Context and Individualistic Attitudes Toward Marriage. Social Psychology Quarterly. 2004; 6(3):236-256.

Barber, Jennifer S.; Shivakoti, Ganesh P.; Axinn, William G.; Gajurel, Kishor. Sampling Strategies for Rural Settings: A Detailed Example from Chitwan Valley Family Study, Nepal. Nepal Population Journal. 1997; 6(5):193-203. 
Basyal, Gopi Krishna; Khanal, Narendra Raj. Process and Characteristics of Urbanisation in Nepal. Contributions to Nepalese Studies. 2001; 28(2):187-225.

Becker, Gary S. Human Capital: A Theoretical and Empirical Analysis, with Special Reference to Education. 3. Chicago: University of Chicago Press; 1994.

Belli, Robert F. The Structure of Autobiographical Memory and the Event History Calendar: Potential Improvements in the Quality of Retrospective Reports in Surveys. Memory. 1998; 6:383-406. [PubMed: 9829098]

Bennett, Lynn. Dangerous Wives and Sacred Sisters: Social and Symbolic Roles of High-Caste Women in Nepal. New York: Columbia University Press; 1983.

Beutel, Ann M.; Axinn, William G. Gender, Social Change, and Educational Attainment. Economic Development and Cultural Change. 2002; 51(1):109-134.

Bista, DB. People of Nepal. Kathmandu: Ratna Pustak Bhandar; 1972.

Blaike, Piers; Cameron, John; Seddon, David. Nepal in Crisis: Growth and Stagnation at the Periphery. Bombay: Oxford University Press Delhi; 1980.

Brauner-Otto, Sarah R.; Axinn, William G.; Ghimire, Dirgha J. The Spread of Health Services and Fertility Transition. Demography. 2007; 44(4):747-770. [PubMed: 18232209]

Caplan, Lionel. Land and Social Change in East Nepal: A Study of Hindu-Tribal Relations. 2. Kathmandu: Himal Books; 2000.

Cerrutti, Marcela; Massey, Douglas S. On the Auspices of Female Migration between Mexico and the United States. Demography. 2001; 38:187-200. [PubMed: 11392907]

Coleman, James S. Social Capital in the Creation of Human Capital. American Journal of Sociology. 1988; 94S:S95-S125.

Conway, Dennis; Shrestha, Nanda R. Causes and Consequences of Rural-to-Rural Migration in Nepal. Bloomington: Indiana University; 1981.

Dahal DR. Rethinking Fertility Transitions: Some Observations from Nepal. Population Dynamics in Nepal. 1993; 2:49-58.

Donato KM. Current Trends and Patterns of Female Migration - Evidence from Mexico. International Migration Review. 1993; 27(4):748-771. [PubMed: 12286924]

Durand, Jorge; Parrado, Emilio A.; Massey, Douglas S. Migradollars and Development: A Reconsideration of the Mexican Case. International Migration Review. 1996; 30:423-44. [PubMed: 12291750]

Fox, John. Applied Regression Analysis, Linear Models, and Related Methods. Thousand Oaks, CA: Sage Publications; 1997.

Freedman, Deborah; Thornton, Arland; Camburn, Donald; Alwin, Duane; Linda Young-DeMarco, L. The Life History Calendar: A Technique for Collecting Retrospective Data. Sociological Methodology. 1988; 18:37-68. [PubMed: 12282712]

Fricke T, Axinn WG, Thornton A. Marriage, Social Inequality, and Women's Contact With Their Natal Families in Alliance Societies: Two Tamang Examples. American Anthropologist. 1993; 95(2):395-419.

Ghimire, Dirgha J.; Axinn, William G. Family Change in Nepal: Evidence from Western Chitwan. Contributions to Nepalese Studies. 2006; 33(2):177-201.

Graner, Elvira. Labor Markets and Migration in Nepal. Mountain Research and Development. 2001; 21(3):253-259.

Graner, Elvira; Gurung, Ganesh. Arab ko lahure: Looking at Nepali Labour Migrants to Arabian countries. Contributions to Nepalese Studies. 2003; 30(2):295-325.

Gurung, Harka Bahadur, et al. Main Report. Kathmandu: HMG Population Commission; 1983. Internal and International Migration in Nepal. 5 parts. [in Nepali ]

Gurung, Harka. Regional Patterns of Internal Migration in Nepal. Honolulu, HI: East-West Population Center; 1989.

Gurung, HB. Vignettes of Nepal. Kathmandu: Sajha Prakashan; 1980.

Gurung, SB. The Land and the People. In: Shumshere, P.; Rana, JB.; Dhungel, DN., editors. Contemporary Nepal. New Delhi: Vikas Publishing House; 1998. p. 1-13. 
Harris JR, Todaro MP. Migration, Unemployment and Development: a Two-Sector Analysis. American Economic Review. 1970; 60(1):126-142.

Hatton, Timothy J.; Williamson, Jeffrey G. What Drove the Mass Migrations from Europe in the Late Nineteenth Century? Population and Development Review. 1994; 20:533-60.

Hatton, Timothy J.; Williamson, Jeffrey G. The Age of Mass Migration: Causes and Economic Impact. Oxford: Oxford University Press; 1998.

HMG, His Majesty's Government of Nepal, National Planning Commission, Central Bureau of Statistics. Nepal Living Standards Survey 2003/04. Kathmandu: Central Bureau of Statistics; 2004.

HMG, His Majesty's Government of Nepal, National Planning Commission Secretariat, Central Bureau of Statistics, and United Nations Population Fund Nepal. Population Census 2001: National Report. Kathmandu: UNFPA; 2002.

Hoelter, Lynette F.; Axinn, William G.; Ghimire, Dirgha J. Social Change, Premarital Non-Family Experiences, and Marital Dynamics. Journal of Marriage and Family. 2004; 66:1131-1151.

Bal Kumar, KC. Migration, poverty and development in Nepal. Economic and Social Commission for Asia and the Pacific; Paper presented at the Ad Hoc Expert Group Meeting on Migration and Development; 27-29 August; Bangkok. 2003.

Bal Kumar, KC. Trends, Patterns, and Implication of Rural to Rural Migration in Nepal. Kathmandu: Central Department of Population Studies, Tribhuvan University; Nepal: 1998.

Kollmair, Michael; Manandhar, Siddhi; Subedi, Bhim; Thieme, Susan. New Figures for Old Stories: Migration and Remittances in Nepal. Migration Letters. 2006; 3(2):151-160.

Lindstrom, David P.; Lauster, Nathaniel. Local Economic Opportunity and the Competing Risks of U.S. and Internal Migration in Zacatecas, Mexico. International Migration Review. 2000; 35:1232-54.

MacFarlane, Alan. Resources and Population: A Study of the Gurungs of Nepal. Cambridge: Cambridge University Press; 1976.

Massey, Douglas S. International Migration and Economic Development in Comparative Perspective. Population and Development Review. 1988; 14:383-414.

Massey, Douglas S. Social Structure, Household Strategies, and the Cumulative Causation of Migration. Population Index. 1990; 56:3-26. [PubMed: 12316385]

Massey, Douglas S.; Alarcon, Rafael; Durand, Jorge; Gonzalez, Humberto. Return to Aztlan: The Social Process of International Migration from Western Mexico. Berkeley: University of California Press; 1990.

Massey, Douglas S.; Arango, Joaquin; Hugo, Graeme; Kouaouci, Ali; Pellegrino, Adela; Edward Taylor, J. Worlds in Motion: International Migration at the End of the Millennium. Oxford: Oxford University Press; 1998.

Massey DS, Espinosa KE. What's Driving Mexico-U.S. migration? A Theoretical, Empirical, and Policy Analysis. The American Journal of Sociology. 1997; 102(4):939.

Massey, Douglas S.; Edward Taylor, J. Back to the Future: Immigration Research, Immigration Policy, and Globalization in the Twenty-first Century. In: Massey, Douglas S.; Edward Taylor, J., editors. International Migration: Prospects and Policies in a Global Market. Oxford: Oxford University Press; 2004. p. 373-88.

Mines, Richard. Network Migration and Mexican Rural Development: A Case Study. In: Jones, Richard C., editor. Patterns of Undocumented Migration: Mexico and the United States. Totowa, NJ: Rowman and Allanheld; 1984. p. 136-158.

Ministry of Population and Environment [Nepal]. Review of Population Policy in Nepal. Kathmandu Nepal: 1998.

Morawska, Ewa. The Sociology and Historiography of Immigration. In: Yans-McLaughlin, Virginia, editor. Immigration Reconsidered: History, Sociology, and Politics. New York: Oxford University Press; 1990. p. 187-240.

Niraula BB, Morgan SP. Marriage Formation, Post-Marital Contact With Natal Kin and Autonomy of Women: Evidence From Two Nepali Settings. Population Studies. 1996; 50(1):35-50.

Pedraza S. Women and Migration: The Social Consequences of Gender. Annual Review of Sociology. $1991 ; 17: 303-325$. 
Petras, Elizabeth M. The Global Labor Market in the Modern World-Economy. In: Kritz, Mary M.; Keely, Charles B.; Tomasi, Silvano M., editors. Global Trends in Migration: Theory and Research on International Population Movements. Staten Island, N.Y: Center for Migration Studies; 1981. p. 44-63.

Pienta, Amy Mehraban; Barber, Jennifer S.; Axinn, William G. Social Change and Adult Children's Attitudes Toward Support of Elderly Parents: Evidence from Nepal. Hallym International Journal of Aging. 2001; 3(2):211-235.

Pokharel, Bola N.; Shivakoti, Ganesh P. Impact of Development Efforts on Agricultural Wage Labor. Winrock Rural Poverty Research Paper Series No. 1.1986

Portes, Alejandro; Walton, John. Labor, Class, and the International System. New York: Academic Press; 1981.

Reed, HB.; Reed, MJ. Nepal in Transition: Educational Innovation. Pittsburgh: University of Pittsburgh Press; 1968.

Reichert, Joshua S. The Migrant Syndrome: Seasonal U.S. Wage Labor and Rural Development in Central Mexico. Human Organization. 1981; 40:56-66.

Sassen, Saskia. The Mobility of Labor and Capital: A Study in International Investment and Labor Flow. Cambridge: Cambridge University Press; 1988.

Seddon, David; Adhikari, Jagannath; Gurung, Ganesh. Foreign Labor Migration and the Remittance Economy of Nepal. Critical Asian Studies. 2002; 34(1):19-40.

Sharma, Pitambar. Population Monograph of Nepal. His Majesty's Government, National Planning Commission Secretariat, Central Bureau of Statistics; Ramshahpath Kathmandu, Nepal: 2003. Urbanization and Development.

Shivakoti, Ganesh P.; Axinn, William G.; Bhandari, Prem; Chhetri, Netra B. The Impact of Community Context on Land Use in an Agricultural Society. Population and Environment. 1999; 20:191-213.

Shivakoti, Ganesh P.; Pokharel, Bola N. Marketing of Major Crops in Chitwan: A Case Study of Six Village Panchayats. Winrock Research Paper Series. 1989; (8)

Shrestha, Nanda R. Frontier Settlement and Landlessness among Himalayan Migrants in Nepal Tarai. Annals of the Association of American Geographers. 1989; 79(3):370-389.

Shrestha, NR.; Bhattarai, K. Historical Dictionary of Nepal. Lanham: The Scarecrow Press; 2003.

Shrestha, Nanda R.; Velu, Raja R.; Conway, Dennis. Frontier Migration and Upward Mobility: The Case of Nepal. Economic Development and Cultural Change. 1993; 41:787-816.

Sjaastad, Larry A. The Costs and Returns of Human Migration. Journal of Political Economy. 1962; 70:80-93.

Stark O, Bloom DE. The New Economics of Labor Migration. American Economic Review. 1985; 75:173-178.

Stark O, Taylor JE. Migration Incentives, Migration Types: The Role of Relative Deprivation. The Economic Journal. 1991; 101:1163-1178.

Stash S, Hannum E. Who Goes to School? Educational Stratification by Gender, Caste, and Ethnicity in Nepal. Comparative Education Review. 2001; 45(3):354-378.

Taylor, J Edward. Remittances, Savings, and Development in Migrant-Sending Areas. In: Massey, Douglas S.; Edward Taylor, J., editors. International Migration: Prospects and Policies in a Global Market. Oxford: Oxford University Press; 2004. p. 157-173.

Taylor, J Edward; Arango, Joaquin; Hugo, Graeme; Kouaouci, Ali; Massey, Douglas S.; Pellegrino, Adela. International Migration and National Development. Population Index. 1996a; 62:181-212. [PubMed: 12292019]

Taylor, J Edward; Arango, Joaquin; Hugo, Graeme; Kouaouci, Ali; Massey, Douglas S.; Pellegrino, Adela. International Migration and Community Development. Population Index. 1996b; 63:397418.

Thieme, Susan; Bhattarai, Raju; Gurung, Ganesh; Kollmair, Michael; Manadhar, Siddhi; MullerBoker, Ulrike. Addressing the Needs of Nepalese Migrant Workers in Nepal and in Delhi, India. Mountain Research and Development. 2005; 25(2):109-114. 
Thieme, Susan; Wyss, Simone. Migration Patterns and Remittance Transfer in Nepal: A Case Study of Sainik Basti in Western Nepal. International Migration. 2005; 43(5):59-96.

Thomas, Brinley. Migration and Economic Growth: A Study of Great Britain and the Atlantic Economy. Cambridge: Canbridge University Press; 1973.

Thomas, Dorothy S. Social and Economic Aspects of Swedish Population Movements: 1750-1933. New York: Macmillan; 1941.

Todaro, Michael P. Internal Migration in Developing Countries. Geneva: International Labor Office; 1976.

Tuladhar, JM. The Persistence of High Fertility in Nepal. New Delhi: Inter-India Publications; 1989.

United Nations Development Programme. Nepal Human Development Report 2004: Empowerment and Poverty Reduction. Kathmandu, Nepal: United Nations Development Programme; 2004.

Williams, Nathalie. Education, Gender, and Migration in Rural Nepal. Paper presented at the Annual Meetings of the Population Association of America; Los Angeles, California. March 2006; 2006.

World Bank Group. Genderstats: Database of Gender Statistics. Washington D.C: World Bank Group; 2004.

Yabiku, Scott. Marriage Timing in Nepal: Organizational Effects and Individual Mechanisms. Social Forces. 2004; 83(2):559-586.

Yabiku, Scott. The Effect of Non-Family Experiences on Age of Marriage in a Setting of Rapid Social Change. Population Studies. 2005; 59(3):339-354. [PubMed: 16249154]

Yabiku, Scott T. Neighbors and Neighborhoods: Effects on Marriage Timing. Population Research and Policy Review. 2006; 25(4):305-327.

Yadav, SR. Migration Problems in Nepal's Tarai. In: Dharamdasani, Murlidhar, editor. Nepal in Transition: Studies on Contemporary Issues and Trends. Varanasi: Shalimar; 1997. p. 46-66. 


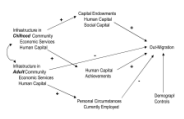

Figure 1.

Conceptual Model of migration and Development 


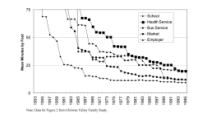

Figure 2.

Change Over Time in Mean Minutes by Foot to the Nearest Public Services 


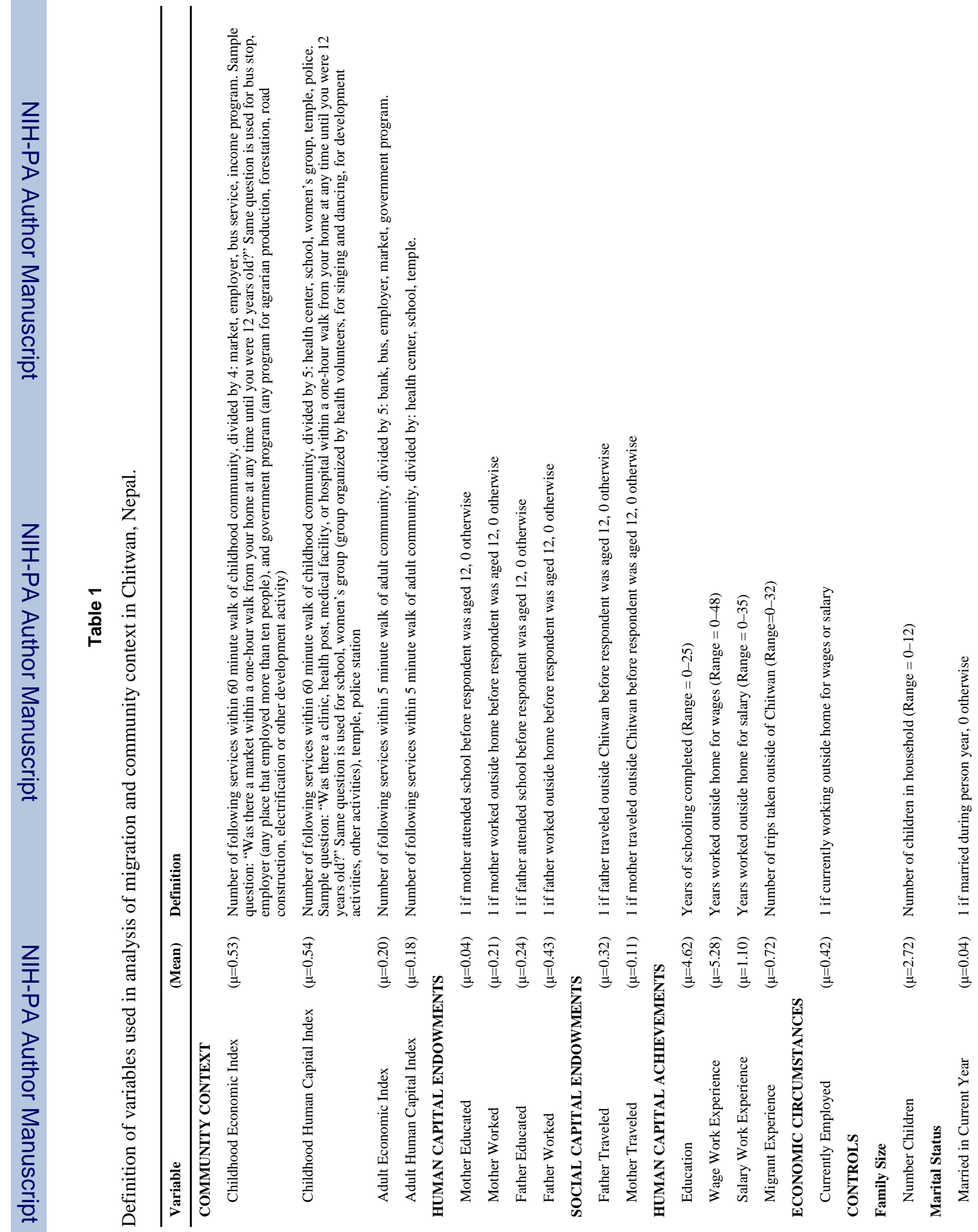




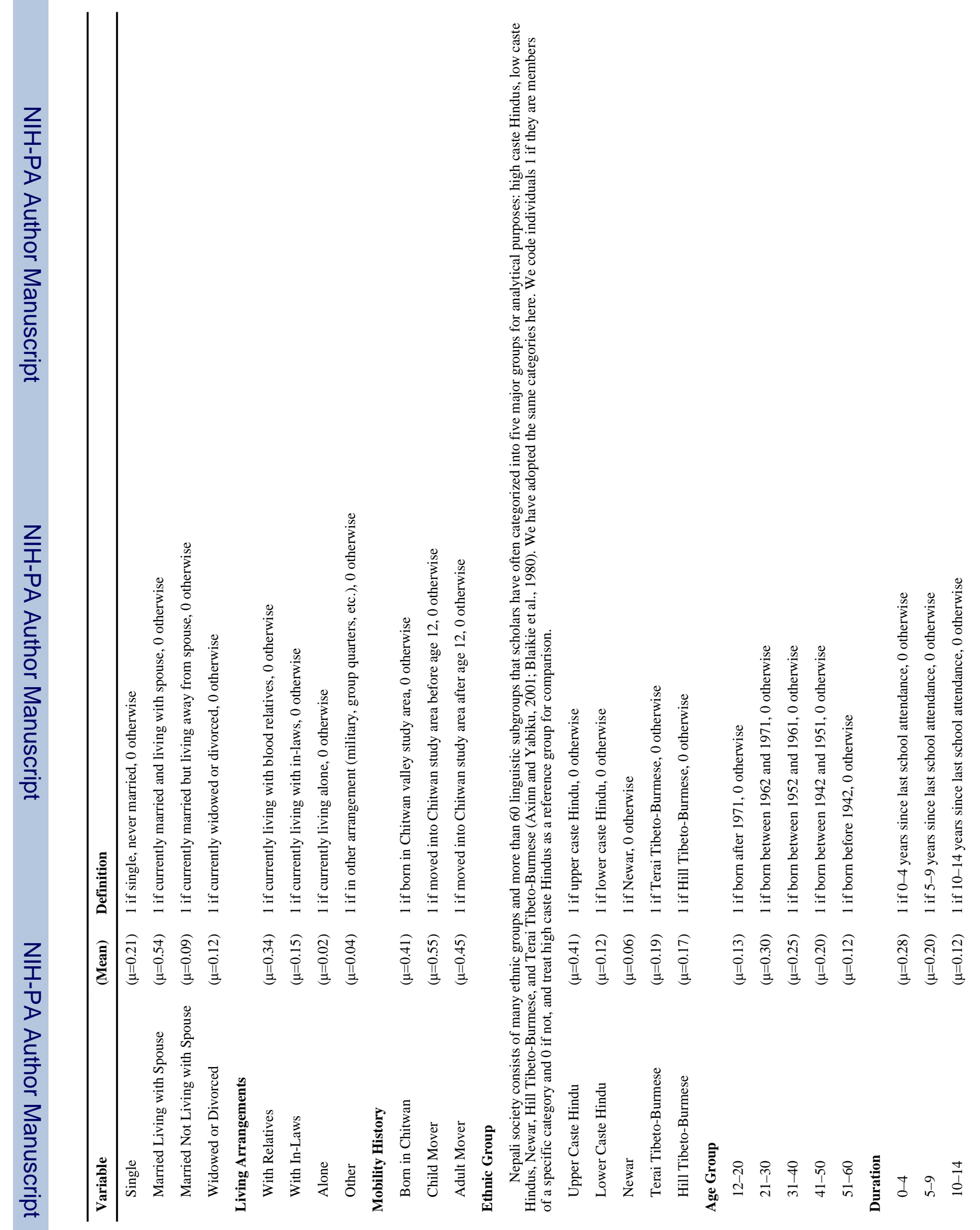




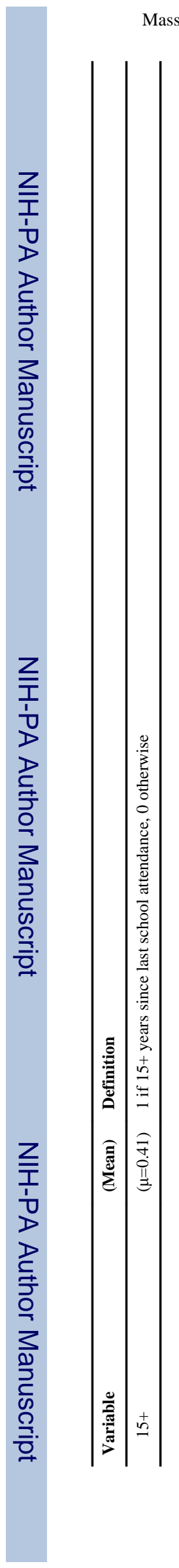

Page 24

Int Migr. Author manuscript; available in PMC 2011 July 29. 
Table 2

Effect of childhood community context on human capital endowments of respondents to Chitwan Valley Family Survey.

\begin{tabular}{|c|c|c|c|c|}
\hline \multirow[b]{2}{*}{ Variable } & \multicolumn{2}{|c|}{ Mother Educated } & \multicolumn{2}{|c|}{ Mother Worked } \\
\hline & B & SE & B & SE \\
\hline \multicolumn{5}{|c|}{ CHILDHOOD COMMUNITY CONTEXT } \\
\hline Economic Index & $1.722 * * *$ & 0.426 & $0.477 * *$ & 0.184 \\
\hline Human Capital Index & 0.686 & 0.496 & $-0.415^{*}$ & 0.221 \\
\hline \multicolumn{5}{|l|}{ CONTROL VARIABLES } \\
\hline \multicolumn{5}{|l|}{ Gender } \\
\hline Female & -0.048 & 0.171 & $-0.463 * * *$ & 0.084 \\
\hline \multicolumn{5}{|l|}{ Mobility History } \\
\hline Born in Chitwan & -0.119 & 0.244 & 0.078 & 0.136 \\
\hline Child Mover & ---- & ---- & --- & --- \\
\hline Adult Mover & 0.214 & 0.253 & -0.155 & 0.136 \\
\hline \multicolumn{5}{|l|}{ Ethnic Group } \\
\hline Upper Caste Hindu & --- & ---- & ---- & ---- \\
\hline Lower Caste Hindu & $-1.444 * * *$ & 0.403 & $1.167 * * *$ & 0.120 \\
\hline Newar & 0.071 & 0.316 & -0.256 & 0.218 \\
\hline Terai Tibeto-Burmese & $-1.130 * * *$ & 0.306 & $0.573 * * *$ & 0.124 \\
\hline Hill Tibeto-Burmese & -0.245 & 0.242 & $0.341 * *$ & 0.123 \\
\hline \multicolumn{5}{|l|}{ Age Group } \\
\hline $12-20$ & ---- & ---- & ---- & ---- \\
\hline $21-30$ & $-0.949 * *$ & 0.192 & -0.067 & 0.123 \\
\hline $31-40$ & $-1.885^{* *}$ & 0.291 & $-0.318^{*}$ & 0.140 \\
\hline $41-50$ & $-1.807^{*}$ & 0.379 & -0.629 **** & 0.170 \\
\hline $51-60$ & -14.306 & 232.300 & $-0.716^{* * * *}$ & 0.207 \\
\hline Intercept & $-3.342 * * *$ & & $-1.192 * * *$ & \\
\hline -2 Log Likelihood & 1110.962 & & 3711.525 & \\
\hline $\mathrm{N}$ & 3,884 & & 3,885 & \\
\hline
\end{tabular}


Table 3

Effect of childhood community context on human capital endowments of respondents to Chitwan Valley Family Survey.

\begin{tabular}{|c|c|c|c|c|}
\hline \multirow[b]{2}{*}{ Variable } & \multicolumn{2}{|c|}{ Father Educated } & \multicolumn{2}{|c|}{ Father Worked } \\
\hline & B & SE & $\mathbf{B}$ & SE \\
\hline \multicolumn{5}{|c|}{ CHILDHOOD COMMUNITY CONTEXT } \\
\hline Economic Index & $0.842 * * *$ & 0.184 & $0.635^{* * * *}$ & 0.149 \\
\hline Human Capital Index & $0.794 * * *$ & 0.226 & $-0.299 *$ & 0.179 \\
\hline \multicolumn{5}{|l|}{ CONTROL VARIABLES } \\
\hline \multicolumn{5}{|l|}{ Gender } \\
\hline Female & $0.239 * *$ & 0.085 & $-0.288^{* * * *}$ & 0.069 \\
\hline \multicolumn{5}{|l|}{ Mobility History } \\
\hline Born in Chitwan & $-0.260 *$ & 0.130 & $-0.300 * *$ & 0.115 \\
\hline Child Mover & ---- & ---- & ---- & --- \\
\hline Adult Mover & -0.001 & 0.127 & 0.142 & 0.108 \\
\hline \multicolumn{5}{|l|}{ Ethnic Group } \\
\hline Upper Caste Hindu & ---- & ---- & ---- & ---- \\
\hline Lower Caste Hindu & $-0.890 * * *$ & 0.149 & $0.743^{* * *} *$ & 0.108 \\
\hline Newar & $0.465^{* *}$ & 0.160 & $0.320^{*}$ & 0.144 \\
\hline Terai Tibeto-Burmese & $-0.855^{* * * *}$ & 0.134 & -0.062 & 0.107 \\
\hline Hill Tibeto-Burmese & -0.205 & 0.120 & $0.639 * * *$ & 0.097 \\
\hline \multicolumn{5}{|l|}{ Age Group } \\
\hline $12-20$ & ---- & ---- & ---- & ---- \\
\hline $21-30$ & $-0.689 * * *$ & 0.116 & $-0.278^{* *}$ & 0.110 \\
\hline $31-40$ & $-1.385^{* * * *}$ & 0.139 & $-0.612^{* * *}$ & 0.122 \\
\hline $41-50$ & $-1.529 * * *$ & 0.169 & $-0.669 * * *$ & 0.140 \\
\hline $51-60$ & $-1.982^{* * * *}$ & 0.235 & $-0.832^{* * * *}$ & 0.165 \\
\hline Intercept & $-0.940 * * *$ & & $-0.307^{*}$ & \\
\hline -2 Log Likelihood & 3639.417 & & 5061.089 & \\
\hline $\mathrm{N}$ & 3,843 & & 3,884 & \\
\hline
\end{tabular}


Table 4

Effect of childhood community context on social capital endowments of respondents to Chitwan Valley Family Survey.

\begin{tabular}{|c|c|c|c|c|}
\hline \multirow[b]{2}{*}{ Variable } & \multicolumn{2}{|c|}{ Father Migrated } & \multicolumn{2}{|c|}{ Mother Migrated } \\
\hline & B & SE & B & SE \\
\hline \multicolumn{5}{|c|}{ CHILDHOOD COMMUNITY CONTEXT } \\
\hline Economic Index & $0.788^{* * *} *$ & 0.160 & $1.196^{* * *}$ & 0.243 \\
\hline Human Capital Index & $0.461 * *$ & 0.195 & $1.266^{* * * *}$ & 0.301 \\
\hline \multicolumn{5}{|l|}{ CONTROL VARIABLES } \\
\hline \multicolumn{5}{|l|}{ Gender } \\
\hline Female & 0.013 & 0.075 & $0.188^{*}$ & 0.111 \\
\hline \multicolumn{5}{|l|}{ Mobility History } \\
\hline Born in Chitwan & -0.491 **** & 0.118 & $-0.846 * * *$ & 0.170 \\
\hline Child Mover & ---- & ---- & ---- & ---- \\
\hline Adult Mover & -0.071 & 0.110 & 0.109 & 0.146 \\
\hline \multicolumn{5}{|l|}{ Ethnic Group } \\
\hline Upper Caste Hindu & ---- & ---- & ---- & ---- \\
\hline Lower Caste Hindu & -0.631 **** & 0.403 & $-0.645^{* * * *}$ & 0.121 \\
\hline Newar & -0.083 & 0.149 & 0.035 & 0.207 \\
\hline Terai Tibeto-Burmese & $-1.130 * * *$ & 0.134 & $-1.265^{* * * *}$ & 0.262 \\
\hline Hill Tibeto-Burmese & $0.204^{*}$ & 0.098 & $0.331 * *$ & 0.140 \\
\hline \multicolumn{5}{|l|}{ Age Group } \\
\hline $12-20$ & ---- & ---- & ---- & ---- \\
\hline $21-30$ & $-0.239 *$ & 0.117 & 0.075 & 0.177 \\
\hline $31-40$ & $-0.347^{* *}$ & 0.131 & -0.019 & 0.196 \\
\hline $41-50$ & -0.233 & 0.151 & 0.273 & 0.220 \\
\hline $51-60$ & $-0.537^{* *}$ & 0.182 & -0.308 & 0.296 \\
\hline Intercept & -0.709 & & $-3.368^{* * * *}$ & \\
\hline -2 Log Likelihood & 4496.872 & & 2391.792 & \\
\hline $\mathrm{N}$ & 3,874 & & 3,887 & \\
\hline
\end{tabular}




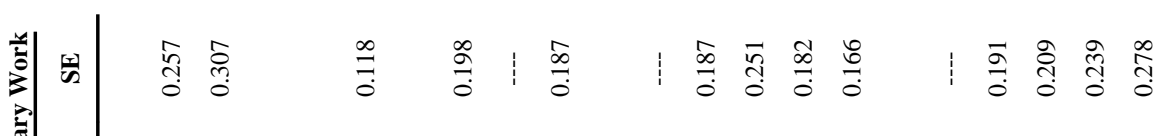

音

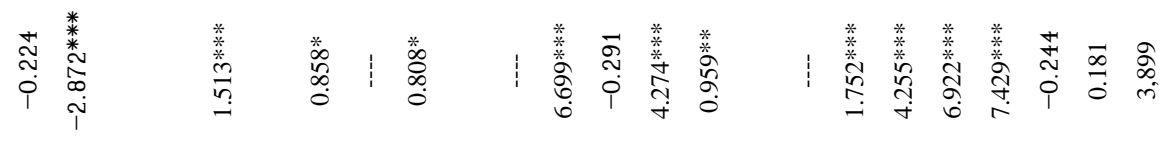

䒺息

ते

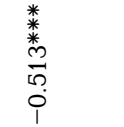

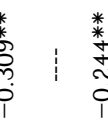

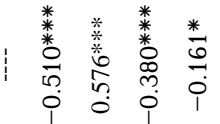

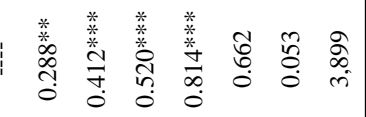

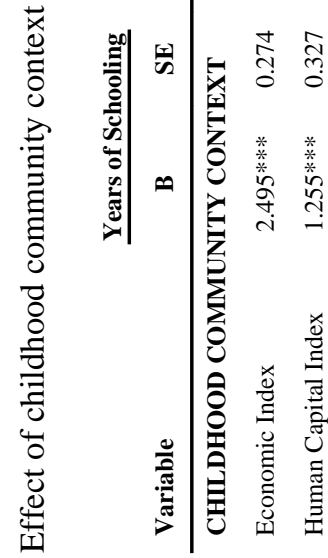

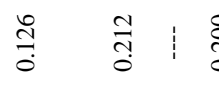

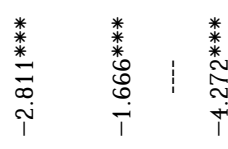

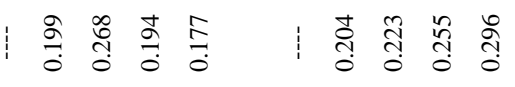

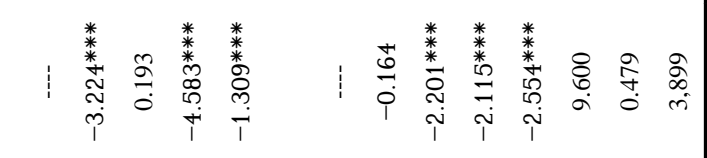


Table 6

Effect of adult community context on current economic status of respondents in Chitwan Valley Family Survey.

\begin{tabular}{|c|c|c|}
\hline \multirow[b]{2}{*}{ Variable } & \multicolumn{2}{|c|}{ Currently Employed } \\
\hline & B & SE \\
\hline \multicolumn{3}{|c|}{ ADULT COMMUNITY CONTEXT } \\
\hline Economic Index & $0.676^{* * * *}$ & 0.163 \\
\hline Human Capital Index & $-0.824 * * *$ & 0.152 \\
\hline \multicolumn{3}{|l|}{ CONTROL VARIABLES } \\
\hline \multicolumn{3}{|l|}{ Gender } \\
\hline Female & $-0.252 * * *$ & 0.070 \\
\hline \multicolumn{3}{|l|}{ Mobility History } \\
\hline Born in Chitwan & 0.233 & 0.119 \\
\hline Child Mover & ---- & ---- \\
\hline Adult Mover & $0.361 * * *$ & 0.113 \\
\hline \multicolumn{3}{|l|}{ Ethnic Group } \\
\hline Upper Caste Hindu & ---- & ---- \\
\hline Lower Caste Hindu & $1.293^{* * *}$ & 0.110 \\
\hline Newar & -0.215 & 0.160 \\
\hline Terai Tibeto-Burmese & $0.939 * * *$ & 0.109 \\
\hline Hill Tibeto-Burmese & $0.213^{*}$ & 0.096 \\
\hline \multicolumn{3}{|l|}{ Age Group } \\
\hline $12-20$ & ---- & ---- \\
\hline $21-30$ & $-0.284 * *$ & 0.112 \\
\hline $31-40$ & -0.133 & 0.120 \\
\hline $41-50$ & -0.133 & 0.131 \\
\hline $51-60$ & $-0.751 * * *$ & 0.153 \\
\hline Intercept & -0.580 & \\
\hline -2 Log Likelihood & 4970.598 & \\
\hline $\mathrm{N}$ & 3,913 & \\
\hline
\end{tabular}


Table 7

Discrete time event history analysis of out-migration from Chitwan Valley, Nepal.

\begin{tabular}{lcc} 
& \multicolumn{2}{c}{ Outcome: Left Chitwan } \\
\cline { 2 - 3 } Variable & B & SE \\
\hline COMMUNITY CONTEXT & & \\
$\quad$ Childhood Economic Index & 0.219 & 0.158 \\
Childhood Human Capital Index & 0.100 & 0.190 \\
Adult Economic Index & $-0.560^{* * *}$ & 0.168 \\
Adult Human Capital Index & $-0.405^{*}$ & 0.192
\end{tabular}

HUMAN CAPITAL ENDOWMENTS

$\begin{array}{lcc}\text { Mother Educated } & 0.425^{*} & 0.191 \\ \text { Mother Worked } & 0.325^{* * *} & 0.088 \\ \text { Father Educated } & -0.029 & 0.093 \\ \text { Father Worked } & -0.022 & 0.073\end{array}$

SOCIAL CAPITAL ENDOWMENTS

$\begin{array}{lcc}\text { Father Migrant } & 0.250^{* *} & 0.086 \\ \text { Mother Migrant } & 0.061 & 0.122\end{array}$

HUMAN CAPITAL ACHIEVEMENTS

$\begin{array}{lcc}\text { Education } & 0.046^{* * *} & 0.010 \\ \text { Wage Work Experience } & 0.011 & 0.010 \\ \text { Salary Work Experience } & 0.016 & 0.015 \\ \text { Migrant Experience } & -0.103^{* *} & 0.040\end{array}$

ECONOMIC CIRCUMSTANCES

Currently Employed $\quad-0.347^{* * *} \quad 0.103$

\section{CONTROL VARIABLES}

Gender

Female

$-1.221^{* * *} \quad 0.100$

Family Size

Number Children

$-0.165^{* * *} \quad 0.035$

Marital Status

Married in Current Year

$0.468^{* * *} \quad 0.130$

Single

--- - - - - - -

Married Living with Spouse

$-0.221^{*} \quad 0.118$

Married Not Living with Spouse

$1.184^{* * *} \quad 0.147$

Widowed or Divorced

0.172

0.160

Living Arrangements

Alone

With Relatives

With In-Laws

$-0.151 \quad 0.158$

Other

$0.410^{* *} \quad 0.176$ 


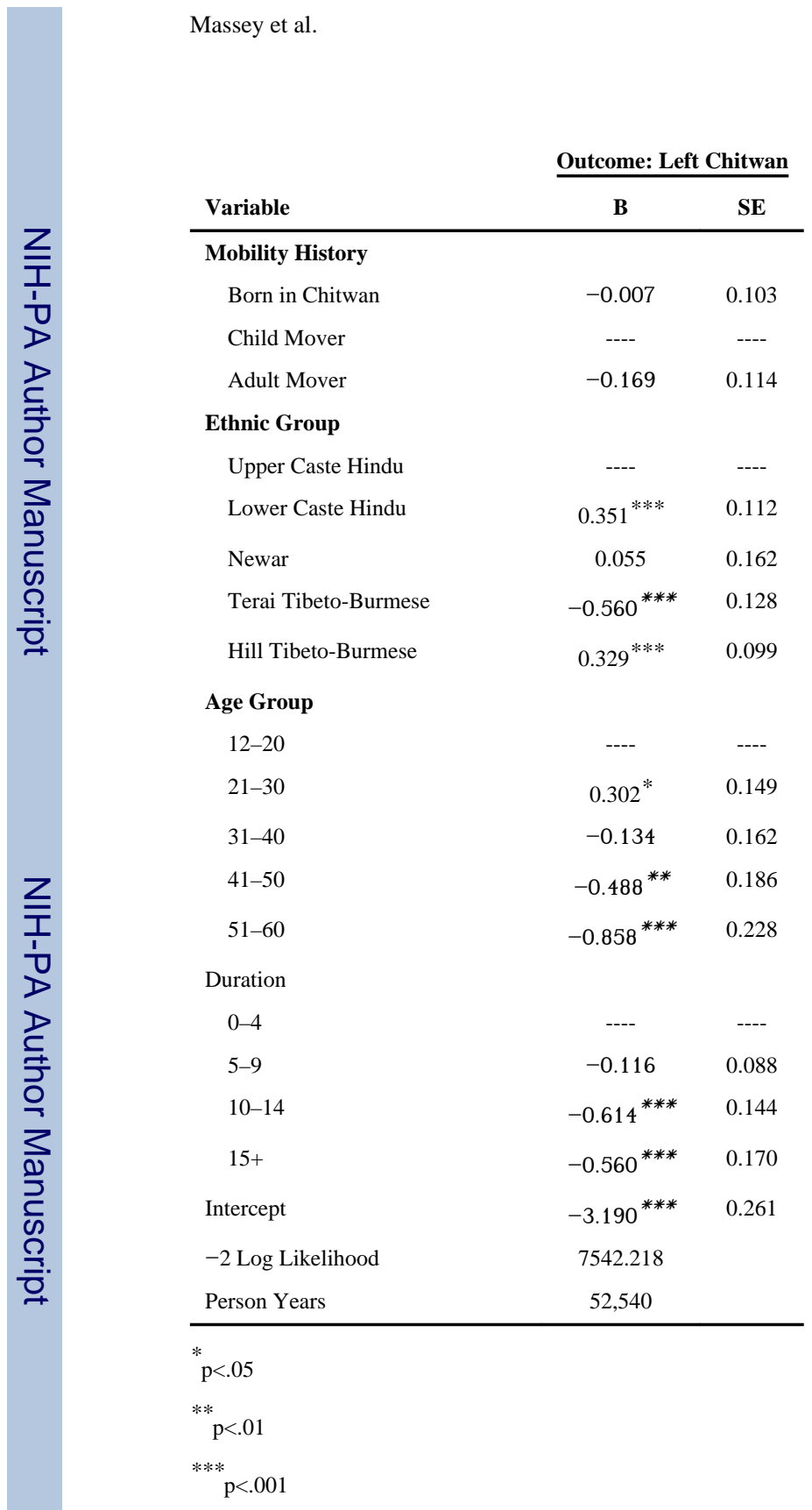




\section{Table 8}

Discrete time event history analysis of male and female out-migration from Chitwan Valley, Nepal.

\begin{tabular}{lcccccc} 
& \multicolumn{2}{c}{ Males } & & \multicolumn{2}{c}{ Females } \\
\cline { 2 - 3 } Variable & B & SE & & B & SE \\
\hline COMMUNITY CONTEXT & & & & & \\
Childhood Economic Index & 0.166 & 0.191 & & 0.227 & 0.290 \\
Childhood Human Capital Index & 0.207 & 0.232 & & 0.094 & 0.342 \\
Adult Economic Index & $-0.949^{* * *}$ & 0.207 & & $0.592^{*}$ & 0.297 \\
Adult Human Capital Index & $-0.469^{*}$ & 0.233 & & -0.299 & 0.339
\end{tabular}

\section{HUMAN CAPITAL ENDOWMENTS}

\begin{tabular}{|c|c|c|c|c|}
\hline Mother Educated & 0.366 & 0.243 & $0.521^{*}$ & 0.315 \\
\hline Mother Worked & $0.255^{* *}$ & 0.102 & $0.439^{* *}$ & 0.174 \\
\hline Father Educated & 0.022 & 0.120 & -0.078 & 0.168 \\
\hline Father Worked & 0.019 & 0.095 & -0.079 & 0.154 \\
\hline \multicolumn{5}{|c|}{ SOCIAL CAPITAL ENDOWMENTS } \\
\hline Father Migrant & $0.248^{* *}$ & 0.101 & $0.315^{*}$ & 0.168 \\
\hline Mother Migrant & 0.049 & 0.152 & 0.062 & 0.215 \\
\hline \multicolumn{5}{|c|}{ HUMAN CAPITAL ACHIEVEMENTS } \\
\hline Education & $0.062^{* * *}$ & 0.012 & 0.002 & 0.020 \\
\hline Wage Work Experience & 0.008 & 0.012 & 0.025 & 0.021 \\
\hline Salary Work Experience & 0.016 & 0.015 & -0.171 & 0.220 \\
\hline Migrant Experience & $-0.127^{* *}$ & 0.044 & -0.042 & 0.103 \\
\hline \multicolumn{5}{|l|}{ ECONOMIC CIRCUMSTANCES } \\
\hline Currently Employed & $-0.367^{* *}$ & 0.121 & -0.301 & 0.207 \\
\hline \multicolumn{5}{|l|}{ CONTROL VARIABLES } \\
\hline \multicolumn{5}{|l|}{ Family Size } \\
\hline Number Children & $-0.094^{* *}$ & 0.040 & $-0.337^{* * *}$ & 0.068 \\
\hline \multicolumn{5}{|l|}{ Marital Status } \\
\hline Married in Current Year & -0.088 & 0.189 & $1.478^{* * *}$ & 0.213 \\
\hline Single & --- & --- & --- & ---- \\
\hline Married Living with Spouse & $-0.424^{* * *}$ & 0.135 & $0.518^{*}$ & 0.274 \\
\hline Married Not Living with Spouse & $0.496^{*}$ & 0.221 & $2.287^{* * *}$ & 0.253 \\
\hline Widowed or Divorced & -0.020 & 0.180 & $0.889^{* *}$ & 0.371 \\
\hline \multicolumn{5}{|l|}{ Living Arrangements } \\
\hline Alone & --- & --- & --- & --- \\
\hline With Relatives & 0.073 & 0.140 & $0.470^{*}$ & 0.239 \\
\hline With In-Laws & 0.128 & 1.017 & -0.183 & 0.194 \\
\hline Other & $0.558^{* *}$ & 0.200 & 0.951 & 0.620 \\
\hline \multicolumn{5}{|l|}{ Mobility History } \\
\hline Born in Chitwan & -0.069 & 0.118 & 0.289 & 45 \\
\hline
\end{tabular}




\begin{tabular}{lccrccc} 
& \multicolumn{2}{c}{ Males } & & \multicolumn{2}{c}{ Females } \\
\cline { 2 - 3 } \cline { 5 - 6 } Variable & B & SE & & \multirow{2}{*}{ B } & SE \\
\hline Child Mover & ---- & --- & & --- & --- \\
Adult Mover & $-0.233^{*}$ & 0.137 & & 0.187 & 0.251
\end{tabular}

\section{Ethnic Group}

Upper Caste Hindu

Lower Caste Hindu

---

Newar

$\begin{array}{llll}0.224 & 0.137 & 0.528^{* *} & 0.200\end{array}$

Terai Tibeto-Burmese

$\begin{array}{llll}-0.118 & 0.205 & 0.226 & 0.275\end{array}$

Hill Tibeto-Burmese

$-0.511^{* * *} 0.148 \quad-0.898^{* * *} 0.277$

$0.252^{*} \quad 0.120 \quad 0.367^{*}$

0.181

Age Group

12-20

21-30

$\begin{array}{llll}--- & --- & --- & ---\end{array}$

$31-40$

$\begin{array}{llll}0.247 & 0.182 & 0.300 & 0.266\end{array}$

$41-50$

$\begin{array}{llll}-0.236 & 0.200 & 0.030 & 0.301\end{array}$

$51-60$

$-0.744^{* * *} \quad 0.229 \quad-0.168 \quad 0.336$

Duration

$0-4$

5-9

10-14

$-1.061^{* * *} \quad 0.275 \quad-0.429 \quad 0.428$

$15+$

Intercept

-2 Log Likelihood

$\begin{array}{cccc}--- & --- & --- & --\end{array}$

$\begin{array}{llll}-0.042 & 0.107 & -0.175 & 0.160\end{array}$

$-0.428^{* *} \quad 0.170 \quad-0.801^{* *} 0.273$

$-0.354^{*} \quad 0.202 \quad-0.976^{* *} 0.324$

$-2.984^{* * *} 0.306-5.490^{* * *} 0.540$

Person Years

$4984.815^{* * *} \quad 2436.095^{* * *}$

p $<.05$

21,828

30,712

$\mathrm{p}<.05$

$\mathrm{p}<.01$

p $<* .001$ 
Table 9

Direct and indirect effects of community context on out-migration from Chitwan.

\begin{tabular}{lc} 
Source of Effect & Effect Size*10 \\
\hline Indirect of Childhood Economic Infrastructure via: & .086 \\
Human Capital Endowments & .024 \\
Social Capital Endowments & .046 \\
Human Capital Achievements & .007 \\
Indirect of Childhood Human Capital Infrastructure via: \\
Human Capital Endowments & .015 \\
Social Capital Endowments & .025 \\
Human Capital Achievements & .046 \\
Indirect Effect of Adult Economic Infrastructure via: \\
Current Employment \\
Indirect Effect of Adult Human Capital Infrastructure via: \\
Current Employment \\
Direct Effect of: \\
Adult Economic Infrastructure \\
Adult Human Capital Infrastructure
\end{tabular}

